\title{
What does the 2001 \\ Census tell us about \\ the new parliamentary \\ constituencies?
}

\author{
Julien Anseau \\ Senior Researcher, House of \\ Commons Library
}

New parliamentary constituency boundaries will come into effect in England, Wales and Northern Ireland by the time of the next general election, with the majority of boundaries used in the 2005 General Election set to change. The constituency boundaries used in Scotland in $\mathbf{2 0 0 5}$ will remain unchanged at the next general election. The article discusses the recent boundary changes, and attempts some analyses based upon population, ethnicity, religion, health and other variables.

\section{Introduction}

Westminster parliamentary constituencies are the areas used to elect members of parliament (MPs) to the House of Commons. At the 2005 General Election there were 646 constituencies, each electing one MP. New constituency boundaries will come into effect in England, Wales and Northern Ireland at the date of the next General Election, with the majority of boundaries used at the 2005 General Election set to change. New constituencies in Scotland were already in place in 2005 and the areas used for elections to the Westminster Parliament will remain unchanged at the next General Election.

There will be much interest among members of parliament, candidates and commentators on the demographic and social profile of seats in the build up to the next British General Election. The aim of this article is to pick out some statistical highlights for parliamentary constituencies in Great Britain on the new boundary basis (Box 1), including population, ethnicity, religion, health, educational qualifications, socio-economic status, employment and housing. This article therefore provides a brief overview of what the 2001 Census tells us about the new parliamentary constituencies in Great Britain ${ }^{1}$ rather than providing an outline of Britain's social geography.

The House of Commons Library Research Paper 2001 Census of Population: Statistics for new parliamentary constituencies provides more detailed statistics and is unique in bringing together census data for England, Wales and Scotland for the new constituencies. 


\section{Box one}

\section{Westminster parliamentary constituencies}

Westminster parliamentary constituencies are the areas used to elect members of parliament (MPs) to the House of Commons, which is the primary legislative chamber of the UK, located in Westminster, London.

At the May 2005 General Election there were 646 constituencies, each electing one MP using the first-past-the-post system. The number of MPs in each part of the UK is as follows:

\begin{tabular}{l|c|c}
\hline Country & $\begin{array}{c}\text { 2005 General Election } \\
\text { Number of constituencies/MPs }\end{array}$ & $\begin{array}{c}\text { Next General Election } \\
\text { Number of constituencies/MPs }\end{array}$ \\
\hline England & 529 & 533 \\
Scotalnd & 59 & 59 \\
Wales & 40 & 40 \\
Northern Ireland & 18 & 18 \\
United Kingdom & 646 & 650 \\
\hline
\end{tabular}

\section{Revised constituency areas}

Constituency boundaries are determined by the boundary commissions for each of England, Scotland, Wales and Northern Ireland. One of the commissions' tasks, required by the Parliamentary Constituencies Act 1986, is to undertake a general review every eight to 12 years with the aim of achieving electoral equality - that is the sizes of the electorates in each constituency are as similar as possible (currently about 70,000 electors, typically reflecting a total population of 90,000). General reviews normally lead to large-scale changes but the commissions may also carry out localised interim reviews, usually to realign parliamentary constituencies with local authorities. These can occur at any time, but usually lead to only minor changes.

Constituencies are generally based on whole or part local authorities (but do not cross county boundaries) unless there is a strong case to straddle boundaries. Each case is decided on its merits, although constituencies may not split electoral wards/divisions. Note that although constituencies are defined to reflect wards at the time of review, the changes are not implemented until the subsequent General Election.

The Fifth General Review was completed in 2007. It will lead to major change in England and Wales at the date of the next General Election, with the majority of constituency boundaries used at the May 2005 General Election set to change. Interim reviews prior to the next General Election are likely to lead to some minor changes to the boundaries defined in the review. The boundary commissions' Fifth Review of parliamentary constituency boundaries was unusual in that for the first time the four commissions' recommendations have been, or will be, implemented separately in a series of stages.

The Fifth General Review for England was laid before Parliament on 26 February 2007 and came into force on 27 June 2007. It will lead to major change in England at the date of the next General Election, with the majority of constituency boundaries different from those used at the May 2005 General Election. The number of constituencies in England will increase from 529 to $533^{2}$.

The Fifth General Review for Parliamentary Constituencies and First General Review of National Assembly for Wales Electoral Regions was completed in January 2006. The Parliamentary Constituencies Assembly Electoral Regions (Wales) Order 2006 came into force on 25 April 2006.
Although parliamentary constituency boundaries changed, the number remains at $40^{3}$.

The Boundary Commission for Scotland is responsible for reviews of constituencies in Scotland for the Westminster Parliament, as detailed in the Parliamentary Constituencies Act 1986 and in Schedule 1 of the Scotland Act 1998. Changes to the statutory rules, as set out in The Scotland Act 1998, required that, for the first periodical review following the Act, the electoral quota for England $(69,934)$ must be used to establish the appropriate number of Scottish seats; a further change to the rules removed the requirement that there be a minimum number of 71 Scottish seats at Westminster. The Boundary Commission for Scotland submitted its final report to the Secretary of State for Scotland on 30 November 2004 recommending there should be 59 Scottish seats at the Westminster Parliament and the new constituencies came into force at the General Election on 5 May $2005^{4}$.

The Boundary Commission for Northern Ireland's Fifth Periodical Report on Parliamentary Constituencies was laid before Parliament on 31 March 2008 with a copy of the draft Parliamentary Constituencies (Northern Ireland) Order 2008 to give effect to the recommendations of the Report without modification. The recommendations of the Commission are that 18 constituencies should be retained for Northern Ireland with revisions made to the boundaries of 12 constituencies ${ }^{5}$. Under the recommendations less than 5 per cent of the Northern Ireland electorate would transfer constituencies ${ }^{6}$.

\section{Key Statistics}

Table 1 shows parliamentary constituencies ranked by population. Although one of the boundary commissions' tasks is to aim to achieve electoral equality, other factors taken into consideration mean that there is a wide variation in population between the largest and smallest constituencies in England, Wales and Scotland, ranging from 132,700 (Isle of Wight) to 26,500 ( $\mathrm{Na}$ h-Eileanan an Iar). However, only a small number of seats are much above or below the UK average and they are very much the exception than the rule. 77 per cent of all constituencies have populations within $\pm 10,000$ of the UK average and the range is even narrower if looking at electorates. The Fifth Review has been the most successful yet in reducing the disparities between seats. In terms of population size, 13 of the 20 largest constituencies are in London, and because urban seats tend to be smaller in area London seats tend to have the highest population densities. Conversely, 14 of the 20 smallest constituency populations are in Wales, and a further five in Scotland.

Birmingham Hodge Hill (29 per cent), East Ham (27 per cent), Bradford East (27 per cent), Birmingham Hall Green (27 per cent) and Blackburn (26 per cent) have the highest proportion of people aged $0-15$.

Seven of the top 10 constituencies with the highest proportion of people aged 16-64 are in London. Map 1 shows the proportion of the population aged 65 and over for the 632 new parliamentary constituencies in England, Wales and Scotland. The constituency with the highest proportion of people aged 65 and over is Christchurch in Dorset with 31 per cent. The top 10 constituencies with the highest proportion of elderly people are located on the coasts of Devon, Dorset, East and West Sussex, Essex and Norfolk. It is acknowledged that parliamentary constituencies with large shares of elderly people tend to be Conservative seats. Notional results for the 2005 General Election confirm this assertion; eight of the top 10 constituencies with the highest proportions of people aged 65 and over would be Conservative seats (North Norfolk and Lewes would be Liberal Democrat seats) ${ }^{7}$.

Table 2 shows that 10 parliamentary constituencies in Great Britain have a majority non-white population, namely East Ham (66 per cent), 
Birmingham Ladywood (64 per cent), Ealing Southall (62 per cent), Brent North (62 per cent), West Ham (60 per cent), Ilford South (55 per cent), Brent Central (53 per cent), Birmingham Hall Green (53 per cent), Leicester East (52 per cent) and Bethnal Green and Bow (50 per cent). Constituencies with high proportions of ethnic minorities are urban seats, particularly in London, Birmingham, Leicester and Bradford (Map 2). Notional results for the 2005 General Election suggest Labour does well in areas with large ethnic minority populations; of the top 10 constituencies with the highest proportion of Asians ${ }^{8}$, nine would be Labour seats. The one exception is Bethnal Green and Bow which the Respect Party would have won. Of the top 20 constituencies with the highest proportion of its population classed as Black ${ }^{9}, 19$ are in London; 35 per cent of the population in Camberwell and Peckham constituency is Black. The Chinese ethnic group is more evenly spread out than other ethnic minority groups, with no clear pattern in its geographical distribution. In no constituency does the Chinese ethnic group form more than 3 per cent of the population.

Table 3 illustrates the different geographic distribution of the main religious groups, based upon a voluntary question in the 2001 Census. Some 41 million people ( 72 per cent) living in Great Britain stated themselves to be Christian. The top 10 constituencies with the highest proportions of Christians are all in the North West. Religion and ethnicity are closely related, and it is therefore not surprising that parliamentary constituencies with high concentrations of people from minority religions are urban Labour seats.

The 2001 Census tells us that 1.6 million Muslims live in Great Britain, 3 per cent of the population. More than a third ( 38 per cent) live in London, 14 per cent live in the West Midlands, 13 per cent in the North West and 12 per cent in Yorkshire and the Humber. There are particularly high concentrations of Muslims in constituencies in East London, Bradford, Birmingham and Blackburn; in Bethnal Green and Bow, nearly 40 per cent of the population is Muslim (Map 3).

Hindus living in Great Britain total 558,000 and accounted for 1 per cent of the population. Hindus are particularly concentrated in three English regions; around half ( 52 per cent) live in London, 12 per cent live in the East Midlands and 10 per cent in the West Midlands. In the new parliamentary constituency of Leicester East, Hindus make up nearly 30 per cent of the population. Brent North, Harrow East and Harrow West also have high concentrations of Hindus. Sikhs total 336,000; in Ealing Southall, nearly one in four people are Sikh. There are 267,000 Jews living in Great Britain, making up 0.5 per cent of the population. They are concentrated in the London region, with more than half (56 per cent) living there. A further 11 per cent live in the East of England and 10 per cent in the North West.

There is a concentration of Jewish people in the parliamentary constituency of Finchley and Golders Green, where they account for one in five people. Other constituencies where Jews make up over 10 per cent of the population are Hendon (17 per cent), Hertsmere (11 per cent), Harrow East and Ilford North (both 10 per cent).

8.6 million people (15 per cent of the population of Great Britain) claim they have no religion.

Table 4 examines indicators associated with deprivation such as limiting long-term illness, no educational qualifications, long-term unemployment and lone parenthood. The proportion of people of working age with a limiting long-term illness ranges from 26 per cent in Merthyr Tydfil and Rhymney to 7 per cent in Windsor. Constituencies with high concentrations of people with a limiting long-term illness are found in the former industrial heartlands, particularly South Wales, Glasgow, Liverpool and areas of the North East (Map 4). Conversely, constituencies in the South East experience the lowest levels. There is a clear divide in voting behaviour between these areas. Notional results for the 2005 General Election suggest that the majority of constituencies with high shares of people with a limiting long-term illness are Labour seats, whereas at the other end of the scale constituencies with low shares of people with a limiting long-term illness are Conservative seats (the only exception in the bottom 10 is Richmond Park which is Liberal Democrat).

In Glasgow North East and Glasgow East, over 50 per cent of people aged 16-74 are without educational qualifications. Five of the top 10 constituencies with the highest proportions of people with no qualifications are in the West Midlands. Again, there is a strong association between no educational attainment and Labour seats. The highest concentration of people who are long-term unemployed, measured as the number of people aged 16-74 who have been unemployed for 2 years as a proportion of all unemployed, is found in Wales (Arfon 41 per cent and Ynys Mon 41 per cent), Merseyside (Liverpool Wavetree 41 per cent, Liverpool Riverside 41 per cent, Liverpool Walton 41 per cent and Bootle 40 per cent), Scotland (Dundee West 41 per cent and Na h-Eileanan an Iar 41 per cent) and Birmingham (Birmingham Northfield 40 per cent and Birmingham Edgbaston 39 per cent). In Birmingham Ladywood, nearly 15 per cent of all households are lone parents with dependent children.

The top 10 parliamentary constituencies with the highest proportions of people aged 16-74 with a university degree (or equivalent qualification) and above are all in London. In Kensington, Hampstead and Kilburn and Cities of London and Westminster, at least 50 per cent of people aged 16-74 have a university degree. This reflects the focus of graduate jobs in London. Walsall North has the lowest share of people with a degree (7 per cent). There are also high concentrations of people working in higher managerial and professional occupations in London constituencies (Table 5).

Map 5 shows there is a North-South divide in terms of the proportion of people aged 16-74 employed in higher managerial and professional occupations. There is no clear association between constituencies with high levels of higher educational attainment/working in higher managerial and professional occupations and seats won by a particular political party. The Conservatives, Labour and Liberal Democrats all have seats in London.

Map 6 shows a large proportion of households in Scotland live in local authority rented housing. This is also the case in some urban areas in England and Wales. In Camberwell and Peckham, nearly 50 per cent of households live in council accommodation (Table 6). With regard to home ownership, there is an urban-rural divide where levels of home ownership are relatively high in rural areas and low in urban areas.

\section{Conclusion}

There is a political need for demographic, social and economic statistics for existing and new Westminster parliamentary constituencies. Political parties and parliamentary candidates need up-to-date and accurate information to know how their respective constituencies compare and have changed. While other elected bodies, particularly local councils, benefit from a wide range of statistics available at local authority level, this was not always the case for parliamentarians. In recent years this has been increasingly recognised by the provision of local area official statistics for a variety of geographies, including parliamentary constituencies. Statistics for employment, unemployment, social security benefits, tax credits and road accidents are a few examples of the growing body of such data in addition to the Census of Population. All of these allow politicians to adapt policy to their own 'patch' and engage 
better with constituents. Previous experience shows that statistics for parliamentary constituencies are published retrospectively by government departments following a General Election only once MPs have been elected for these areas. However, it should be recognised that the areas are already 'up and running' with candidates already in place who require understanding of the demographic, social and economic make-up of their local area. 2001 Census data for these areas presented in this article are hopefully the first of what will be a growing set of official statistics that would ideally be in parallel to the existing areas in the run-up to the next UK General Election.

The new parliamentary constituencies will also be those in place at the time of the 2011 Census of Population. The House of Commons Library Research Paper 2001 Census of Population: Statistics for new parliamentary constituencies will provide continuity and comparability between the 2001 and 2011 censuses.

\section{Other sources}

- House of Commons Library Research Paper (2008) 2001 Census of Population: Statistics for new parliamentary constituencies. London www. parliament.uk/commons/lib/research/rp2008/rp08-038.pdf

- Neighbourhood Statistics www.statistics.gov.uk/neighbourhoodstatistics.asp

- Scotland's Census Results Online www.scrol.gov.uk/scrol/common/ home.jsp

- Colin Rallings and Michael Thrasher (2007) Media guide to the new parliamentary constituencies. Plymouth, LGC Elections Centre (contains 2005 General Election notional results)

- House of Commons Library Research Paper (2006) 2005 General Election. London www.parliament.uk/commons/lib/research/rp2005/ rp05-033.pdf

\section{Acknowledgements}

The author wishes to acknowledge the work of the Census team at ONS who provided data for the new constituency areas in England and Wales, and to anonymous reviewers for their helpful suggestions.

\section{References}

1 Statistics for Northern Ireland are not included because 2001 Census statistics for the proposed new constituencies in Northern Ireland are not yet available.

2 The Boundary Commission for England's Fifth Periodical Report provides additional details on the boundary change process Boundary Commission for England, Fifth Periodical Report, $\mathrm{Cm}$ 7032. Available at: www.official-documents.gov.uk/document/ cm70/7032/7032.pdf

3 Boundary Commission for Wales, Fifth Periodical Report, HC 743-I. Available at: www.bcomm-wales.gov.uk/fifth_review_e.htm

4 Boundary Commission for Scotland, Fifth Periodical Report for Westminster constituencies. Available at: www.bcomm-scotland.gov. uk/5th_westminster/5th_westminster.htm

5 Minister of State for Northern Ireland, Written Ministerial Statement 31 March 2008. Available at: www.boundarycommission.org.uk/ pubs/written_ministerial_statement-31March2008.DOC

6 Available at: www.boundarycommission.org.uk/index.html

7 Notional results are estimates of what the results of the 2005 General Election would have looked like if the votes had been counted on the basis of the new boundaries. Notional results, however, are not a prediction of what will happen at the next General Election nor a prediction of how people might have voted had the new boundaries been in force.

8 Includes Indians, Pakistanis and Bangladeshis.

9 Includes Black Caribbean, Black African and Black Other. 


\section{Table 1}

Population in area

Constituency

\section{Highest}

Isle of Wight

West Ham

Holborn and St Pancras

Croydon North

East Ham

Kensington

Hampstead and Kilburn

Brent Central

Slough

Brent North

Kingston and Surbiton

Leeds Central

Tottenham

Birmingham, Hall Green

Bermondsey and Old Southwark

Banbury

Hammersmith

Birmingham, Hodge Hill

Knowsley

Croydon Central

Lowest

Blaenau Gwent

Wirral West

Clwyd West

Delyn

Cynon Valley

Glasgow North

Clwyd South

Wrexham

Carmarthen East and Dinefwr

Brecon and Radnorshire

Ynys Môn

Aberavon

Ross, Skye and Lochaber

Dwyfor Meirionnydd

Montgomeryshire

Caithness, Sutherland and Easter Ross

Arfon

Aberconwy

Orkney and Shetland

Na h-Eileanan an lar
Population size, density and population by age bands

Population density in area

\begin{tabular}{|l|l|l}
\hline Constituency & Nr of persons & Rank
\end{tabular}

\section{Highest}

Kensington

129.9

Islington North

123.9

Chelsea and Fulham

120.3

121,400

Hackney North and Stoke Newington

117.4

Westminster North

116.5

Vauxhall

Islington South and Finsbury

115.6

116,500

114,800

114,500

113,700

110,800

109,700

109,600

109,500

108,900

108,400

108,200

107,900

107,800

107,400

107,300

Bethnal Green and Bow

Bermondsey and Old Southwark

Streatham

112.3

110.7

104.0

97.7

Population aged 0-15 years

Constituency

\% Rank

Highest

$70,100 \quad 613$

70,000

69,700

69,600

69,300

69,000

68,100

67,700

67,100

66,900

66,800

63,200

62,400

60,200

59,500

59,400

56,600

54,700

41,200

26,500

Nottingham North
Birmingham, Hodge Hill

East Ham

Bradford East

Birmingham, Hall Green

Blackburn

Birmingham, Ladywood

Bradford West

West Ham

Hackney North and Stoke Newington

Population aged $16-64$ years

Constituency

Highest

Cities of London and Westminster $\quad 76.2 \quad 1$

Bristol West

Battersea

Hampstead and Kilburn

Glasgow North

Hammersmith

Tooting

Kensington

Cambridge

Vauxhall

29.1

26.9

26.8

26.6

26.4

26.0

25.7

25.5

24.7

24.3

1

1

1
2

3

4

4
5

4
5

6

6

7
8

7
8

9

10

Population aged 65 and over

\begin{tabular}{lcc} 
Constituency & $\%$ & Rank \\
\hline Highest & & \\
Christchurch & 30.9 & 1 \\
Clacton & 30.2 & 2 \\
Worthing West & 28.1 & 3 \\
New Forest West & 27.9 & 4 \\
Bexhill and Battle & 27.0 & 5 \\
East Devon & 26.2 & 6 \\
North Norfolk & 26.1 & 7 \\
Eastbourne & 25.4 & 8 \\
West Dorset & 24.6 & 9 \\
Lewes & 24.2 & 10
\end{tabular}




\section{Table 2}

Ethnicity

Non-White population in area

\begin{tabular}{|l|c|c|}
\hline Constituency & $\%$ & Rank \\
\hline
\end{tabular}

\section{Highest}

East Ham

Birmingham, Ladywood

Ealing, Southall

Brent North

West Ham

Ilford South

Brent Central

Birmingham, Hall Green

Leicester East

Bethnal Green and Bow

Croydon North

Birmingham, Perry Barr

Bradford West

Poplar and Limehouse

Camberwell and Peckham

Birmingham, Hodge Hill

Harrow East

Tottenham

Harrow West

Lewisham, Deptford

$\begin{array}{lr}65.5 & 1 \\ 64.0 & 2 \\ 62.4 & 3 \\ 62.3 & 4 \\ 55.9 & 5 \\ 54.9 & 6 \\ 53.0 & 7 \\ 52.8 & 8 \\ 52.0 & 9 \\ 50.4 & 10 \\ 49.3 & 11 \\ 48.9 & 12 \\ 47.4 & 13 \\ 46.7 & 14 \\ 46.0 & 15 \\ 45.6 & 16 \\ 45.3 & 17 \\ 44.9 & 18 \\ 43.0 & 19 \\ 42.8 & 20\end{array}$

Indian/Pakistani/Bangladeshi population in area

Constituency

Highest

Leicester East

Ealing, Southall

Bradford West

Birmingham, Hall Green

Bethnal Green and Bow

East Ham

Birmingham, Hodge Hill

Birmingham, Ladywood

Ilford South

Brent North

Poplar and Limehouse

Birmingham, Perry Barr

Harrow East

Leicester South

Bradford East

Feltham and Heston

Slough

Blackburn

Harrow West

West Ham

$\%$

44.0

44.0
42.5

41.7

40.5

39.2

37.3

36.4

36.2

35.2

34.6

32.0

30.6

29.8

29.0

28.1

27.8

26.9

26.4

22.7

21.8
Indian population in area

\begin{tabular}{l|c|c}
\hline Constituency & $\%$ & Rank \\
\hline Highest & & \\
Leicester East & 42.1 & 1 \\
Ealing, Southall & 35.4 & 2 \\
Brent North & 29.6 & 3 \\
Harrow East & 27.4 & 4 \\
Leicester South & 25.0 & 5
\end{tabular}

Pakistani population in area

\section{Constituency}

Highest

Bradford West

\% Rank

Birmingham, Hodge Hill

Birmingham, Hall Green

Bradford East

Birmingham, Ladywood

$\begin{array}{ll}34.6 & 1 \\ 31.4 & 2 \\ 27.8 & 3 \\ 22.0 & 4 \\ 17.5 & 5\end{array}$

Chinese population in area

Constituency

$\% \quad$ Rank

\section{Highest}

Hendon

Poplar and Limehouse

Manchester Central

Cities of London and Westminster

Bermondsey and Old Southwark

Black population in area

Constituency

Rank

Highest

Camberwell and Peckham

Lewisham, Deptford

Tottenham

Vauxhall

Hackney South and Shoreditch

Brent Central

West Ham

Croydon North

Dulwich and West Norwood

2.7

Streatham

Hackney North and Stoke Newington

Bermondsey and Old Southwark

Edmonton

Birmingham, Ladywood

East Ham

Lewisham East

Leyton and Wanstead

Walthamstow

Lewisham West and Penge

Greenwich and Woolwich

$\%$

35.2

2.7

2.6

2.3

2.2

35.2
30.2

28.6

28.2

27.8

25.9

25.1

23.9

22.9

22.3

21.8

20.5

18.6

18.6

18.0

17.7

17.3

17.0

16.8

14.6
.

(1)

Rank

1

1
2
3

3
4

3
4

5


Religion (England and Wales)

Table 3

\section{rang}

Christian

Constituency

\section{Highest}

Makerfield

Sefton Central

Wigan

St Helens North

St Helens South and Whiston

Knowsley

Workington

Ribble Valley

Copeland

Leigh

\section{Muslim}

Constituency

\section{Highest}

Bethnal Green and Bow

Bradford West

Birmingham, Hall Green

Poplar and Limehouse

East Ham

Birmingham, Ladywood

Blackburn

Bradford East

West Ham

\section{Sikh}

Constituency

\section{Highest}

Ealing, Southall

Feltham and Heston

Warley

Birmingham, Perry Barr

Hayes and Harlington

Ilford South

Wolverhampton South East

Slough

Wolverhampton South West

West Bromwich East
Birmingham, Hodge Hill

.

\begin{tabular}{|l|l|l}
\hline & $\%$ & Rank \\
\hline
\end{tabular}

Hindu

\begin{tabular}{lcc}
\hline Constituency & $\%$ & Rank \\
\hline Highest & 29.5 & 1 \\
Leicester East & 27.8 & 2 \\
Brent North & 23.9 & 3 \\
Harrow East & 18.3 & 4 \\
Harrow West & 12.4 & 5 \\
Ealing, Southall & 11.0 & 6 \\
Brent Central & 10.5 & 7 \\
llford South & 10.0 & 8 \\
East Ham & 8.7 & 9 \\
Leicester South & 8.7 & 10 \\
Hendon & &
\end{tabular}

\section{Jewish}

\begin{tabular}{lll} 
Constituency & $\%$ & Rank \\
\hline Highest &
\end{tabular}

Finchley and Golders Green

Hendon

$\begin{array}{rr}19.6 & 1 \\ 17.3 & 2 \\ 11.3 & 3 \\ 10.3 & 4 \\ 10.3 & 5 \\ 9.0 & 6 \\ 8.9 & 7 \\ 8.1 & 8 \\ 7.5 & 9 \\ 7.0 & 10\end{array}$

Hertsmere

Harrow East

Ilford North

Hackney North and Stoke Newington

Bury South

Hampstead and Kilburn

Chipping Barnet

Leeds North East

\begin{tabular}{lcc}
\hline No religion & & \\
Constituency & $\%$ & Rank \\
\hline Highest & 33.1 & 1 \\
Bristol West & 32.7 & 2 \\
Brighton, Pavilion & 29.4 & 3 \\
Rhondda & 27.3 & 4 \\
Norwich South & 27.1 & 5 \\
Cambridge & 26.4 & 6 \\
Nottingham East & 25.5 & 7 \\
Sheffield Central & 25.3 & 8 \\
Nottingham North & 25.1 & 9 \\
Islwyn & 25.1 & 10 \\
Blaenau Gwent & & \\
\hline
\end{tabular}

The census form in Scotland contained two voluntary questions on religion, one asking about current religion to which the person belongs and an additional one asking for the religion in which the person was brought up. Due to these differences with England \& Wales, statistics are not directly comparable. 
Table 4

Deprivation indicators

\section{(1)}

Limiting long-term illness (working ages)

Constituency

\section{Highest}

Merthyr Tydfil and Rhymney

Easington

Rhondda

Glasgow North East

Glasgow East

Aberavon

Cynon Valley

Blaenau Gwent

Liverpool, Walton

Glasgow South West

\begin{tabular}{lll}
\hline Lowest & & \\
\hline Henley & 7.7 & 623 \\
Maidenhead & 7.7 & 624 \\
Runnymede and Weybridge & 7.7 & 625 \\
Wimbledon & 7.5 & 626 \\
Esher and Walton & 7.5 & 627 \\
Beaconsfield & 7.4 & 628 \\
Richmond Park & 7.4 & 629 \\
North East Hampshire & 7.3 & 630 \\
Wokingham & 7.1 & 631 \\
Windsor & 7.0 & 632 \\
\end{tabular}

Long-term unemployed ${ }^{1}$

\section{Constituency}

Highest

Arfon

Ynys Môn

Liverpool, Wavertree

Liverpool, Riverside

Dundee West

$\mathrm{Na}$ h-Eileanan an Iar

Liverpool, Walton

Birmingham, Northfield

Bootle

Birmingham, Edgbaston

$\%$ Rank

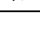

41.3

40.7

40.7

40.6

40.5

40.5

40.5

39.8

39.6

39.2
No qualification

\begin{tabular}{lcc}
\hline Constituency & $\%$ & Rank \\
\hline Highest & & \\
Glasgow North East & 52.0 & 1 \\
Glasgow East & 50.4 & 2 \\
Birmingham, Hodge Hill & 49.4 & 3 \\
Walsall North & 48.6 & 4 \\
West Bromwich West & 47.7 & 5 \\
Wolverhampton South East & 47.6 & 6 \\
Glasgow South West & 47.2 & 7 \\
Rhondda & 47.2 & 8 \\
Merthyr Tydfil and Rhymney & 45.7 & 9 \\
West Bromwich East & 45.5 & 10
\end{tabular}

\section{Lowest}

Finchley and Golders Green

623

Ealing Central and Acton

15.8

15.2

623

Hampstead and Kilburn

15.0

624

Twickenham

Chelsea and Fulham

$14.9 \quad 626$

$14.1 \quad 627$

Cities of London and Westminster $\quad 13.7 \quad 628$

Kensington

Wimbledon

13.5

13.3

12.9

629

Bristol West

Richmond Park

12.3

631

632

Lone parents with dependent children (one family)

\begin{tabular}{lcc} 
Constituency & $\%$ & Rank \\
\hline Highest & & \\
Birmingham, Ladywood & 14.8 & 1 \\
Liverpool, Walton & 13.3 & 2 \\
Glasgow East & 13.2 & 3 \\
Nottingham North & 12.9 & 4 \\
Manchester Central & 12.6 & 5 \\
Tottenham & 12.5 & 6 \\
Knowsley & 12.5 & 7 \\
Birkenhead & 12.4 & 8 \\
West Ham & 12.4 & 9 \\
Glasgow South West & 12.2 & 10
\end{tabular}

$1 \%$ of all unemployed 
Table 5

Higher education and socio-economic classification

Degree (or equivalent) and above (all aged 16-74)

Constituency

\section{Highest}

Kensington

Hampstead and Kilburn

Cities of London and Westminster

Chelsea and Fulham

Battersea

Richmond Park

Wimbledon

Hornsey and Wood Green

Ealing Central and Acton

Putney

\section{Lowest}

Birmingham, Hodge Hill

Dagenham and Rainham

Ashfield

Nottingham North

Liverpool, Walton

Stoke-on-Trent North

Glasgow East

Kingston upon Hull East

West Bromwich West

Walsall North
Higher managerial \& professional (all aged 16-74)

\begin{tabular}{|l|c|c|}
\hline Constituency & $\%$ & Rank \\
\hline
\end{tabular}

\section{Highest}

Kensington

$35.3 \quad 1$

Chelsea and Fulham

Twickenham

Richmond Park

Hampstead and Kilburn

Battersea

Hammersmith

Cities of London and Westminster

Finchley and Golders Green

Ealing Central and Acton

31.7

28.9

26.8

25.7

24.5

24.5
22.6

22.2

21.9

21.9

Lowest

Rotherham

623

Middlesbrough

624

Liverpool, Walton

625

West Bromwich West

626

Swansea East

Merthyr Tydfil and Rhymney

Rhondda

627

628

Stoke-on-Trent North

Dwyfor Meirionnydd

Aberavon

1
2
3
4
5
6
7
8
9
10

623
624
625
626
627
628
629
630
631
632

630

631

632 
Table 6 Housing tenure (households)

\section{Table 6}

Own outright, Shared ownership or with mortgage/loan

Constituency

\section{Highest}

Castle Point

Wyre and Preston North

Sefton Central

Rayleigh and Wickford

Cheadle

East Dunbartonshire

Charnwood

Fareham

South Leicestershire

Mid Derbyshire

York Outer

Old Bexley and Sidcup

Solihull

Haltemprice and Howden

Harborough

Sutton Coldfield

North Somerset

Ribble Valley

South West Devon

Thornbury and Yate

\section{Lowest}

Tottenham

West Ham

Liverpool, Riverside

Glasgow North East

Greenwich and Woolwich

Leeds Central

Westminster North

Hackney North and Stoke Newington

Birmingham, Ladywood

Islington North

Cities of London and Westminster

Manchester Central

Poplar and Limehouse

Holborn and St Pancras

Islington South and Finsbury

Vauxhall

Bethnal Green and Bow

Camberwell and Peckham

Hackney South and Shoreditch

Bermondsey and Old Southwark
Local Authority rented

\begin{tabular}{lcc}
\hline Constituency & $\%$ & Rank \\
\hline Highest & & \\
Camberwell and Peckham & 48.3 & 1 \\
Bermondsey and Old Southwark & 44.1 & 2 \\
Sheffield, Brightside and Hillsborough & 39.3 & 3 \\
Bethnal Green and Bow & 39.3 & 4 \\
Islington South and Finsbury & 39.1 & 5 \\
Barking & 38.2 & 6 \\
Motherwell and Wishaw & 36.9 & 7 \\
Glasgow North East & 36.7 & 8 \\
Nottingham North & 36.6 & 9 \\
Manchester Central & 36.4 & 10
\end{tabular}

\section{Housing Association}

Constituency

$\%$

Highest

Liverpool, Riverside

Hackney South and Shoreditch

23.9

Basingstoke

Kensington

Brent Central

Workington

Hackney North and Stoke Newington

Birmingham, Ladywood

Bedford

Erith and Thamesmead

23.9

22.2

19.9

19.3

18.4

18.4

18.1

18.0

17.4

16.8

Rank

Rented privately

Constituency

$\%$

Rank

Cities of London and Westminster

Westminster North

Bristol West

Hampstead and Kilburn

Kensington

Tooting

Chelsea and Fulham

Brighton, Pavilion

Hornsey and Wood Green

Manchester, Withington

$\begin{array}{rr}38.8 & 1 \\ 32.5 & 2 \\ 31.9 & 3 \\ 31.0 & 4 \\ 30.1 & 5 \\ 27.3 & 6 \\ 26.9 & 7 \\ 26.1 & 8 \\ 26.0 & 9 \\ 25.7 & 10\end{array}$




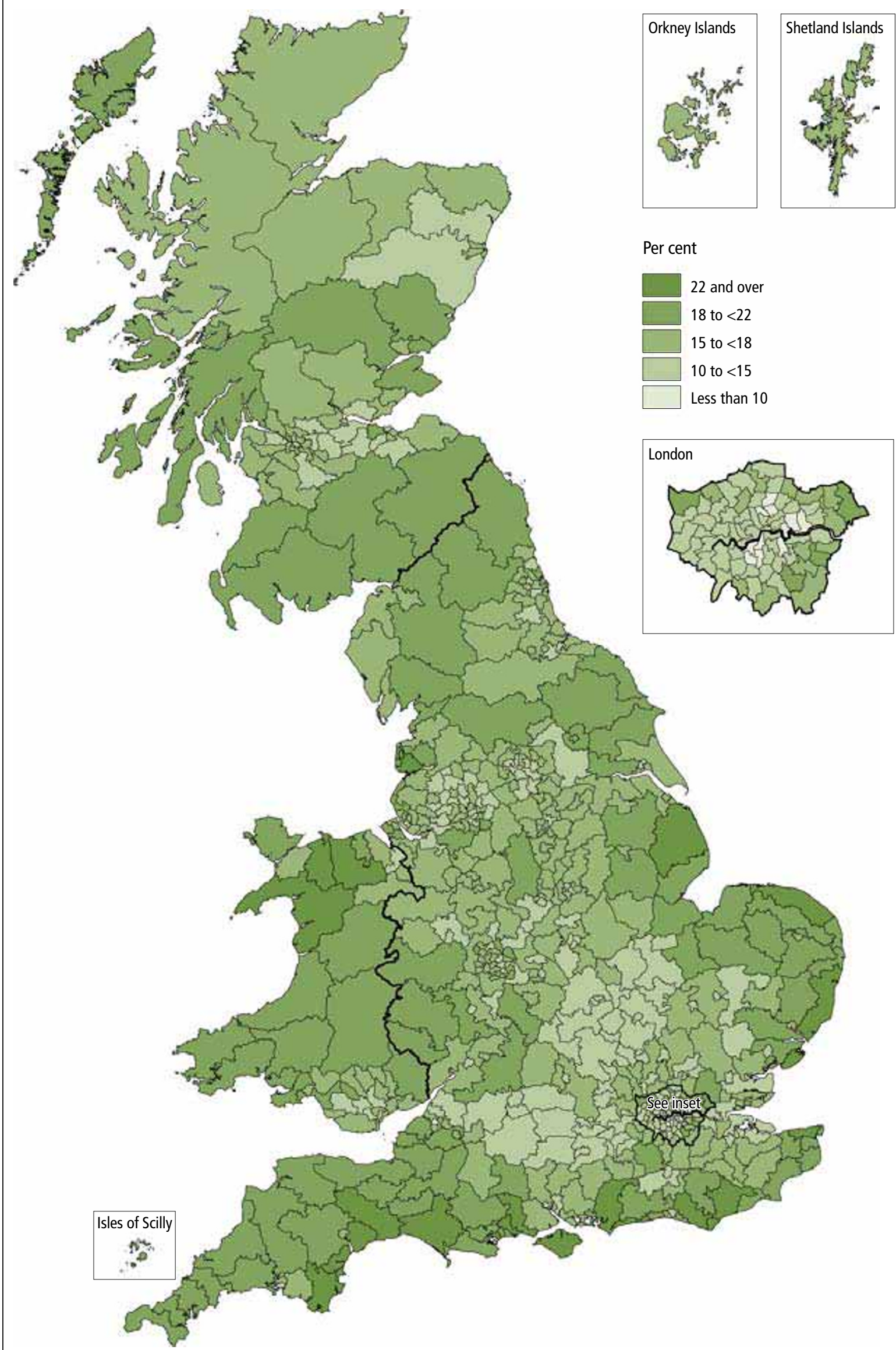




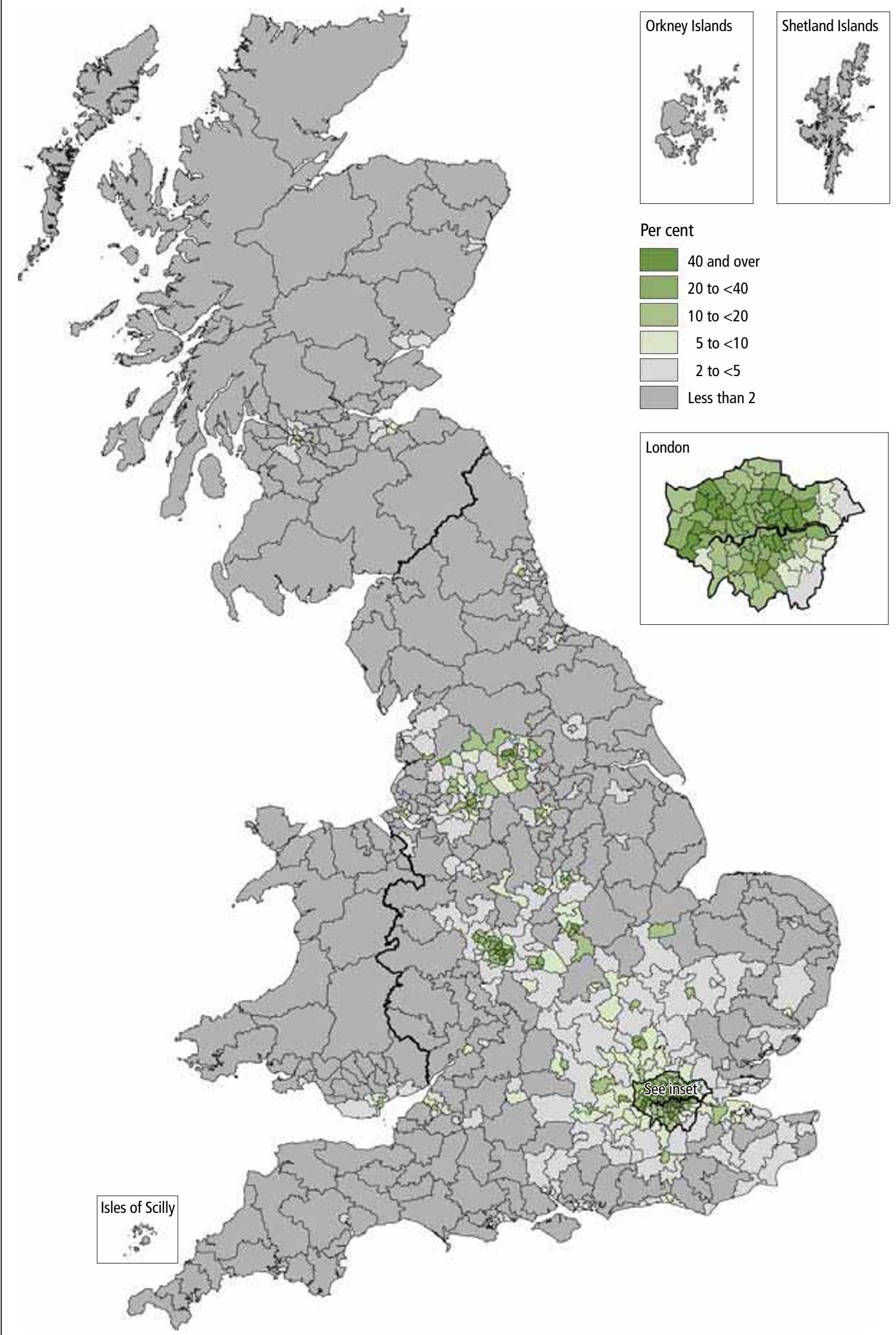




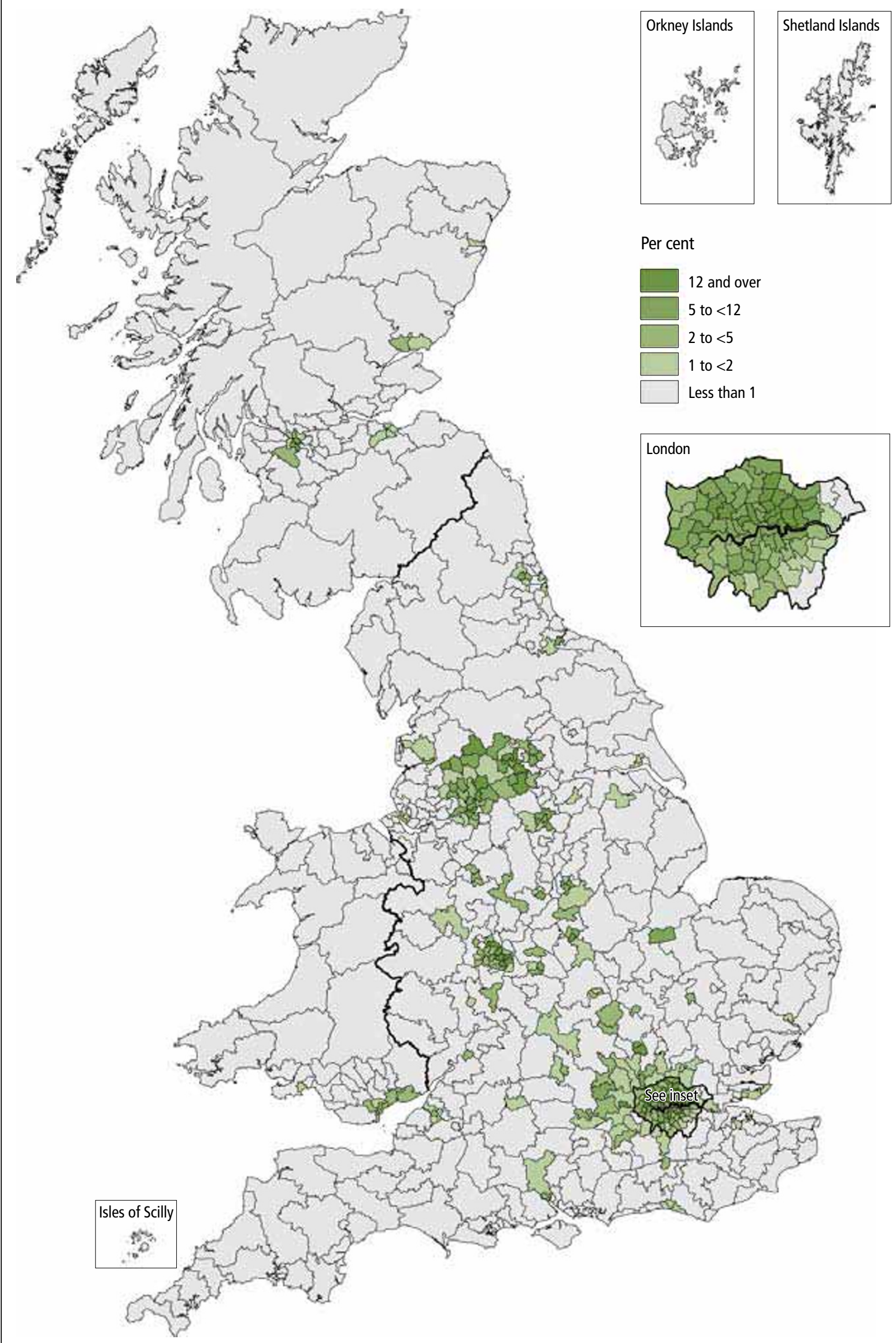


Great Britain: Percentage of the working age (16-64 years) constituency population with Limiting Long Term Illness, 2001 Census

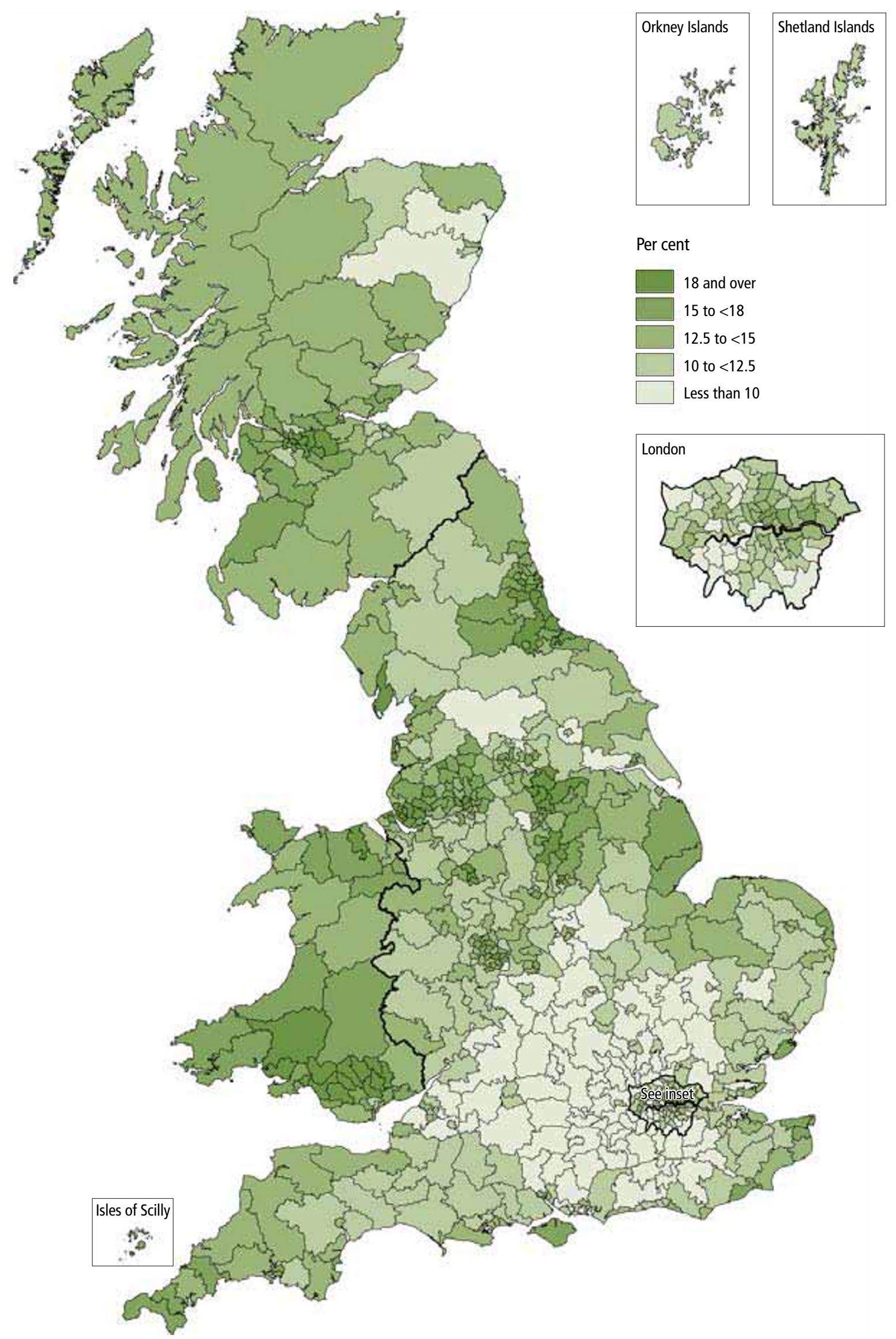




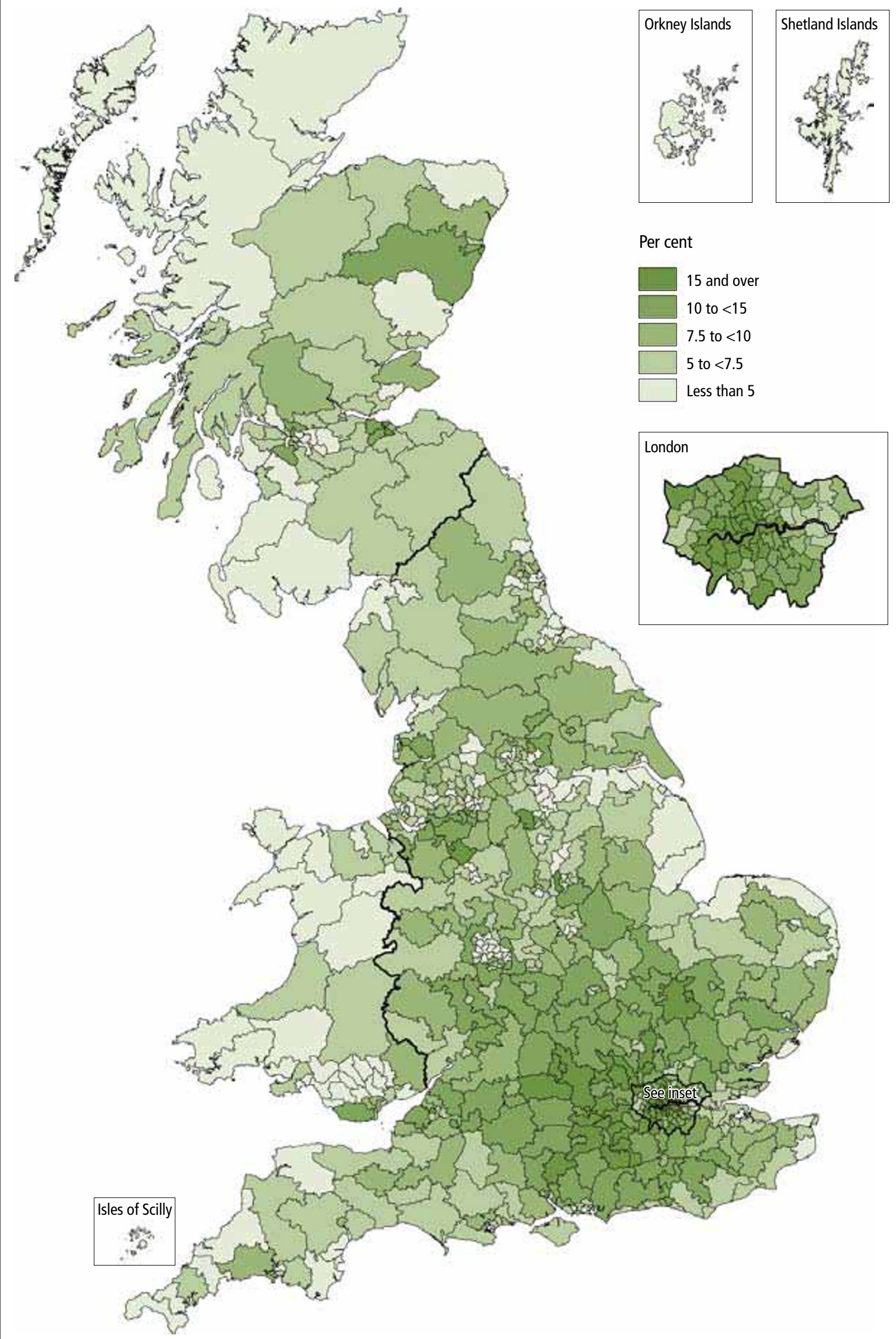



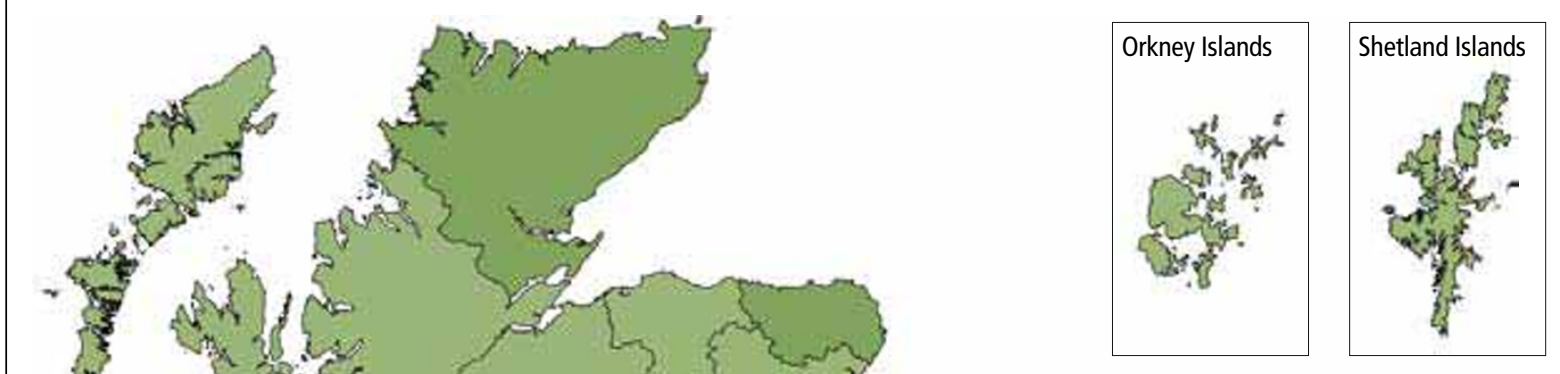

Per cent
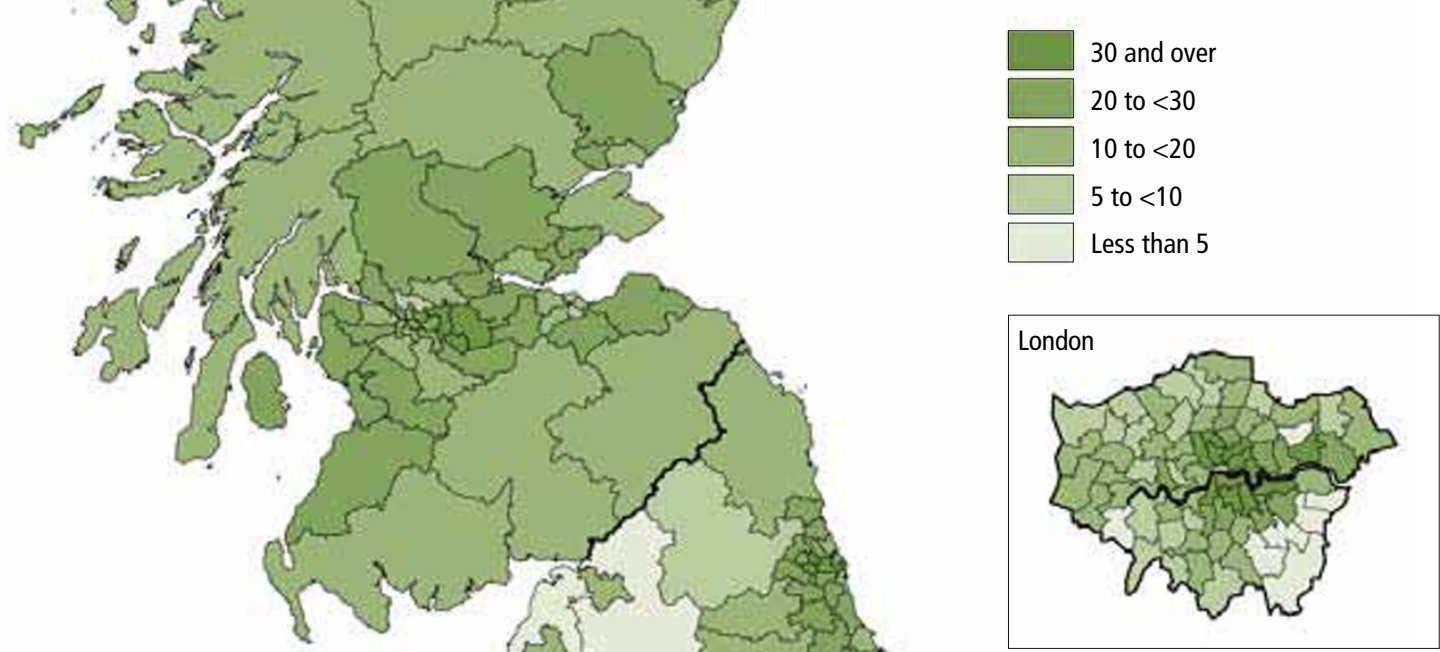